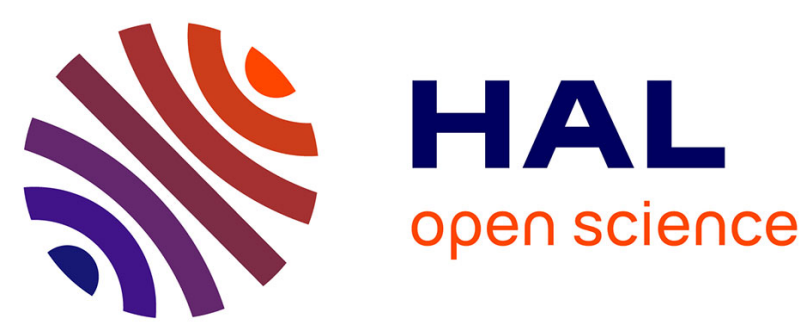

\title{
U-Series Dates for Stalagmitic Flowstone E (Riss/Würm Interglaciation) at Grotte du Lazaret, Nice, France
}

Christophe Falguères, Henry de Lumley, Bischoff James.L

\section{To cite this version:}

Christophe Falguères, Henry de Lumley, Bischoff James.L. U-Series Dates for Stalagmitic Flowstone E (Riss/Würm Interglaciation) at Grotte du Lazaret, Nice, France. 1991. halshs-00405681

\section{HAL Id: halshs-00405681 https://shs.hal.science/halshs-00405681}

Submitted on 20 Jul 2009

HAL is a multi-disciplinary open access archive for the deposit and dissemination of scientific research documents, whether they are published or not. The documents may come from teaching and research institutions in France or abroad, or from public or private research centers.
L'archive ouverte pluridisciplinaire HAL, est destinée au dépôt et à la diffusion de documents scientifiques de niveau recherche, publiés ou non, émanant des établissements d'enseignement et de recherche français ou étrangers, des laboratoires publics ou privés. 


\title{
U-Series Dates for Stalagmitic Flowstone E (Riss/Würm Interglaciation) at Grotte du Lazaret, Nice, France
}

\author{
Christophe Falguères and Henry de Lumley
}

Institut de Paléontologie Humaine, 1 rue René Panhard, 75013 Paris, France

AND

\author{
JAMES L. BISCHOFF \\ U.S. Geological Survey, Menlo Park, California 94025
}

Received January 31, 1991

\begin{abstract}
Several samples of stalagmitic flowstone (Ensemble E) at Grotte du Lazaret (Nice, France) were dated by U-series isotopes. The results show that this speleothem began to grow about 130,000 yr B.P. and continued to about 70,000 yr B.P., coinciding almost exactly with the last interglaciation (isotope stage 5). Even though Ensemble $\mathrm{E}$ is not in direct stratigraphic relation with the cave deposits, this study shows that the Acheulian artifacts industry and fauna within Lazaret are older than the Riss/Wurm interglaciation. (1) 1992 University of Washington.
\end{abstract}

\section{INTRODUCTION}

Grotte du Lazaret is located on the western slope of Mount Boron on the eastern border of the city of Nice (Fig. 1). The cave was originally excavated during the nineteenth century. The results of more recent excavations during the 1950 s by Octobon were published in 1965 . During the 1960 s the de Lumleys began a systematic excavation of the cave which continues today (de Lumley, 1969).

The cave is a vast cavity of some $35 \mathrm{~m}$ long and 4 to $14 \mathrm{~m}$ wide, and has a ceiling height of about $10 \mathrm{~m}$. The archaeological levels (Figs. 2a and $2 \mathrm{~b}$ ) include some $7 \mathrm{~m}$ of section that have been interpreted (de Lumley, 1969; de Lumley and Tavoso, 1969) to range in age from the second ("Mindel/ Riss') interglaciation, represented by beach deposits at the base, up through paleosols and flowstone deemed to have formed during the last ("Riss/Würm") interglaciation through Würm I. The bulk of the deposits are interpreted to belong to the "Riss" interval. It is this section that contains Acheulian lithic tools and human remains, including a deciduous left upper in- cisor, a lower right canine, and a right parietal (de Lumley, 1973). The human remains were discovered in layers V2B and VIII of the Locus VIII, a small cavity at the left of the cave entrance (Fig. 3) associated with Acheulian lithics. The human remains have been interpreted as pre-Neanderthal (de Lumley and Piveteau, 1969). The characteristic mammal remains of the upper layers are Dicerorhinus hemitoechus, Coelodonta antiquitatis, Equus caballus piveteaui, Canis lupus mediterraneus, Lynx spelea, and Panthera spelea. The presence of an archaic horse and a big panther, the degree of evolution reached by the wolf, and rodent remains such as Pliomys lenki all suggest that the fauna is later middle Pleistocene in age (de Lumley et al., 1976).

The mouth of the cave is $26 \mathrm{~m}$ above sea level and located some $100 \mathrm{~m}$ inland from the present Mediterranean shoreline. The shoreline appears to be emergent, and the succession of the cave deposits can be interpreted in terms of this emergence coupled with climatic change. The cave is now damp and stalagmitic flowstone is forming in the cave. When the mouth of the cave first appeared above sea level a gravel now 

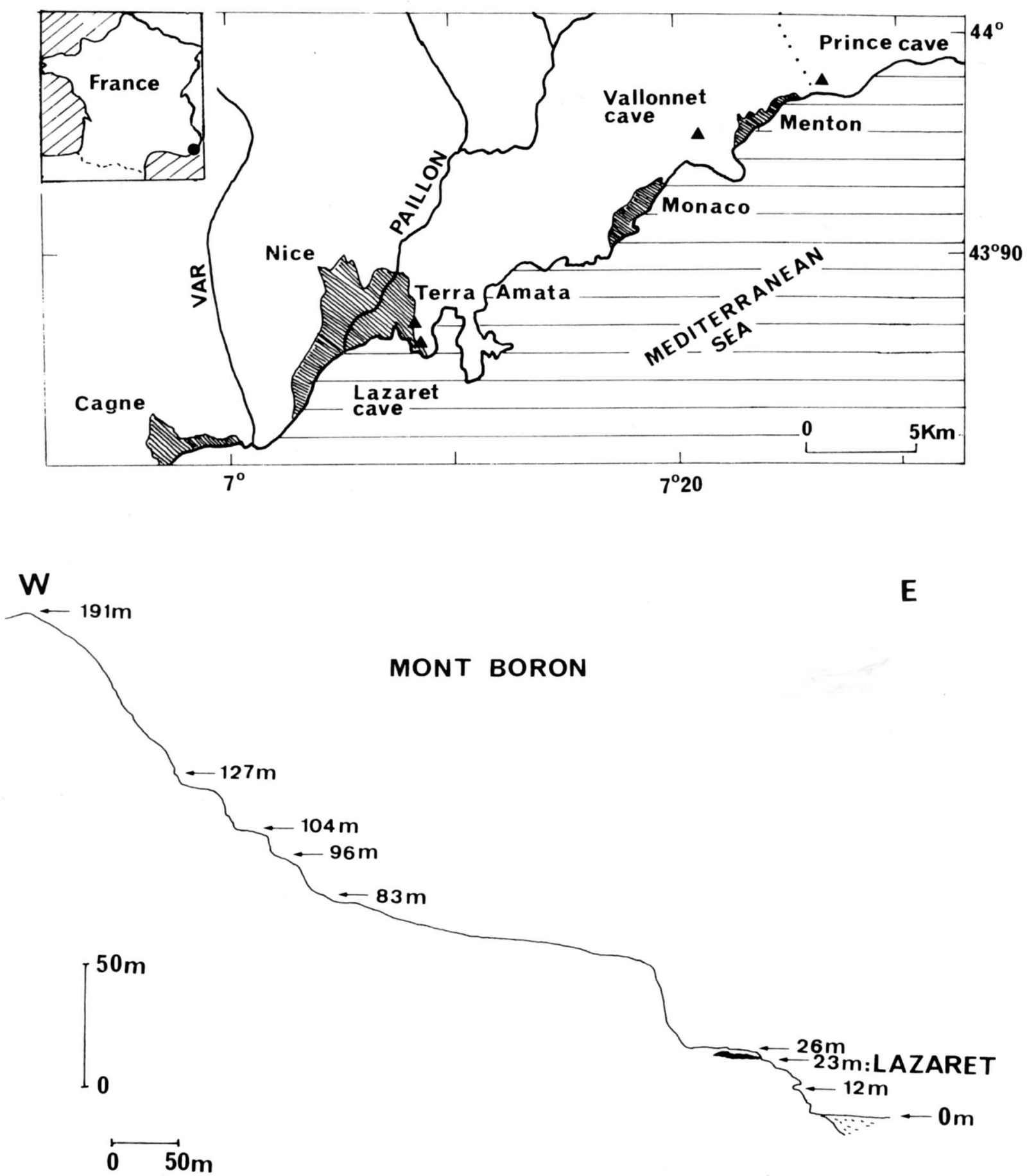

FIG. 1. Map and section showing location of Lazaret cave in the Nice region and on Mont Boron, France.

comprising the basal conglomerate was deposited by wave action. Mollusc shells occur within the conglomerate and some of the cobbles contain holes created by the rock-boring clam Follus. Presumably these deposits formed at a time when sea level was rising at about the same rate as the rate of uplift of the tectonic block that contains the cave. Such conditions would occur at the beginning of an interglaciation when melting of the ice sheets was rapid. As the rate of sea-level rise slowed and the sea reached a steady level, the mouth of the cave continued to rise, isolating it from the sea. The cave became dry and was inhabited by humans who continued to inhabit it throughout the relative dry intervening glacial period. At the beginning of the next interglaciation the rising sea level did not reach the now-elevated mouth of the cave. 

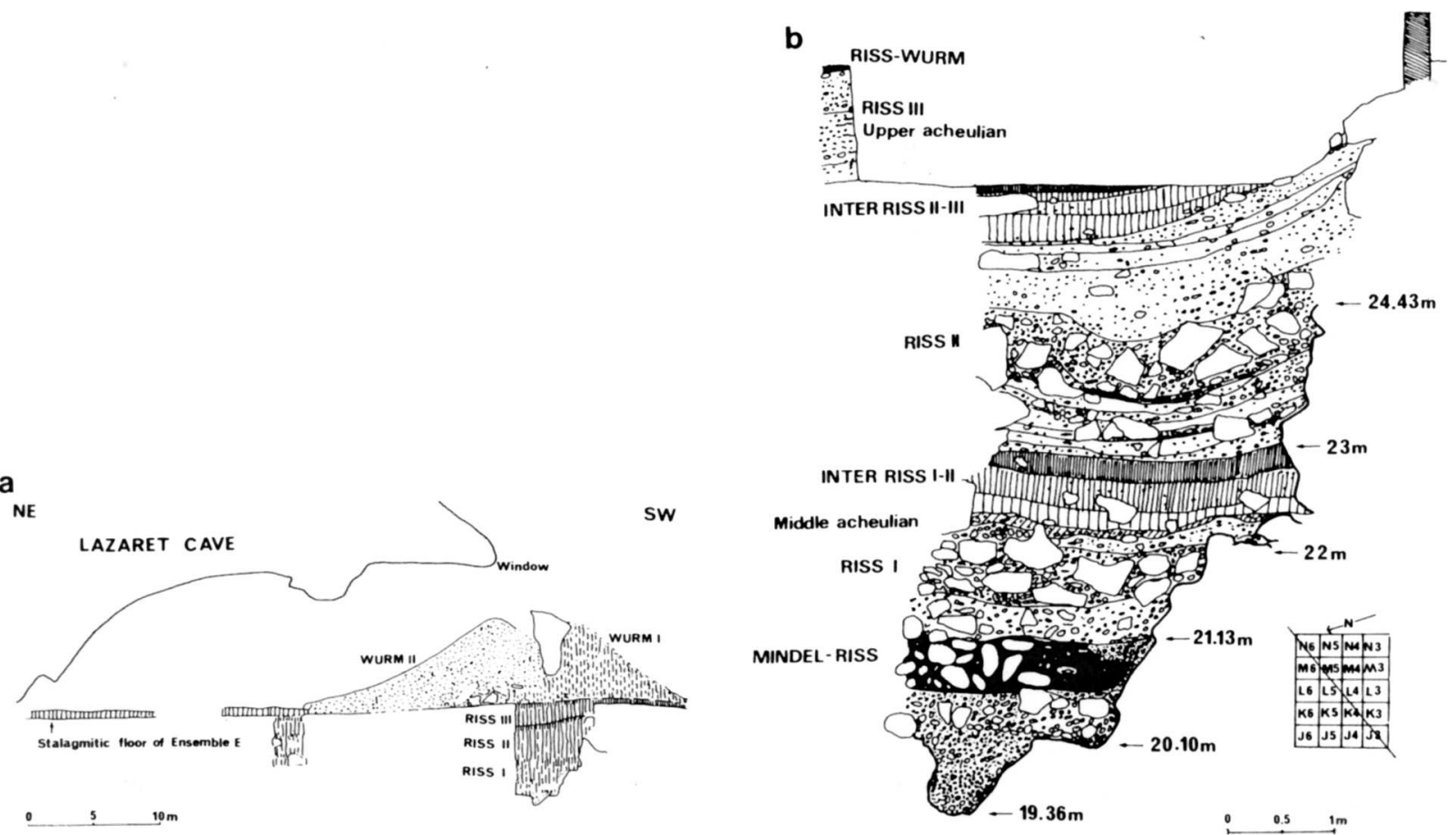

Fig. 2. (a) Generalized longitudinal stratigraphy of Lazaret cave. The continental deposits have been interpreted by de Lumley and Tavoso (1969) as belonging to the "Riss" period. These sediments correspond to a wet and very cold climate. Three distinct ensembles have been displayed (Riss I, Riss II, and Riss III) which are likely equivalent to the three major Riss cold periods. (b) Generalized transverse stratigraphy of Lazaret cave. This cross section was made in the pit located at the entrance of the cave (indicated by the square section in the lower right corner). In this part of the cave (excavation area), there is no direct contact between the continental deposits and the stalagmitic floor. However, it is assumed that the latter overlies Riss III layers. The numbers on the right of the section indicate the several shoreline traces of the transgressive beaches.

This interglacial period was characterized by wet conditions in the cave, represented by a paleosol near the mouth that grades into stalagmitic flowstone toward the rear of the cave (Ensemble E) (Fig. 2a).

The present study was undertaken to date the flowstones of Ensemble $\mathrm{E}$ in order to test this interpretation. Our results indicate that the flowstone began to form about $130,000 \mathrm{yr}$ B.P. and continued to grow until about $70,000 \mathrm{yr}$ B.P. thereby spanning the time range of marine isotope stage 5 .

\section{ENSEMBLE E}

Ensemble $\mathrm{E}$ is a homogeneous and compact stalagmitic floor that extends from the central part to the rear of the cave. In the center of the cave, just within the excavation area, the flowstone overlies red plastic clays that belong to the most recent Riss III layers. The flowstone reaches a thickness of $30 \mathrm{~cm}$ and is composed of well- crystallized pure calcite. Bedding is well defined on a scale of $1-3 \mathrm{~cm}$.

\section{PREVIOUS DATING}

Shen (1985) obtained U-series ages for 5 samples of flowstone of Ensemble $\mathrm{E}$ in the central part of the cave, two from the upper surface, one from the middle, and one from the bottom (Fig. 3). The two stop samples yielded ages of 61,000 and $63,000 \mathrm{yr}$ B.P. by both ${ }^{230} \mathrm{Th}$ and ${ }^{231} \mathrm{~Pa}$ techniques, the intermediate $86,000 \mathrm{yr}$, and the base $100,000 \mathrm{yr}$ B.P. by ${ }^{230} \mathrm{Th}$ alone.

A fossil marine shell, Spondylus gaederopodus, extracted from the beach deposits at the base, was dated by the U-Th method (Stearns and Thurber, 1965). The resulting age of $110,000 \pm 10,000 \mathrm{yr}$ B.P. is significantly younger than had been expected from its local stratigraphic position, which led the authors to consider the sample as having been contaminated. 


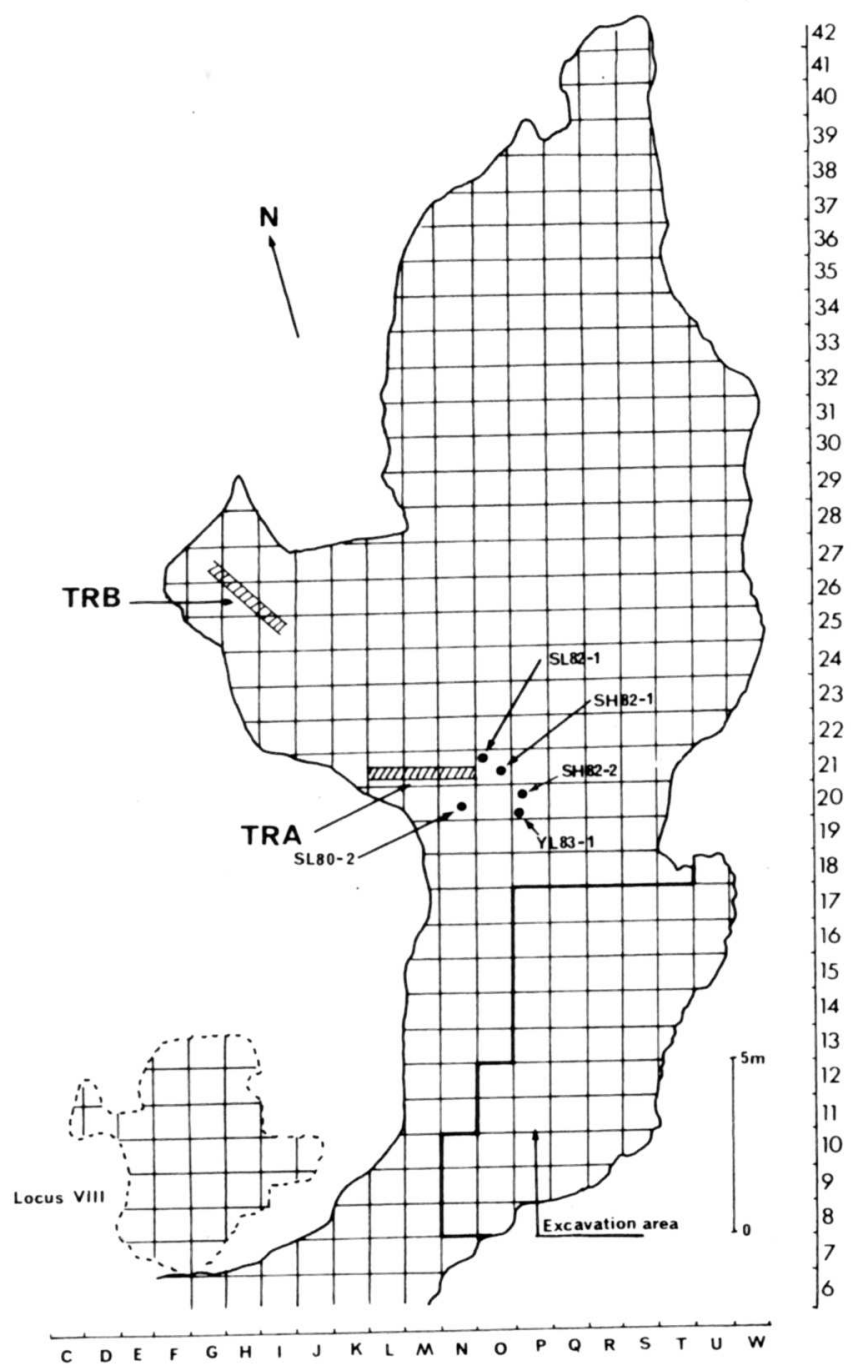

FIG. 3. Plan of excavation squares showing Shen's (1985) samples from Ensemble E, and location of TRA and TRB of present study.

\section{SAMPLING AND ANALYTICAL TECHNIQUES}

During 1987 two trenches, TRA and TRB, were cut with diamond saws into Ensemble $\mathrm{E}$ in the locations shown on Figure 3. At the same time, 12 drill cores $(\mathrm{J}, \mathrm{K}, \mathrm{L}$, $\left.\mathrm{A} 2, \mathrm{H}, \mathrm{P}, \mathrm{P}^{\prime}, \mathrm{Q}\right)$ of the flowstone section of up to $17 \mathrm{~cm}$ long were taken along the edges of the trenches and these were sampled for further U-series analyses (Figs. 4a and 4b). Samples were selected from these cores to demark regions between obvious bedding laminae. For more-massive units, a point sample was taken representing about $1 \mathrm{~cm}$ of section. For example, A2a refers to sample " $a$ " $(0-2 \mathrm{~cm})$ from core A2 obtained in trench TRA (Fig. 4a). In all, 22 samples were analyzed at the U.S. Geological Survey's Menlo Park laboratory.
Samples were dissolved in nitric acid, uranium and thorium isotopes were isolated via ion exchange, and isotopes were counted by $\alpha$ spectroscopy using standard methods described by Bischoff et al. (1988).

\section{RESULTS AND DISCUSSION}

In general, the samples are well crystallized and were free of significant insoluble residue. Isotopic compositions (Table 1) are rather homogeneous from sample to sample, with $U$ content ranging between 0.15 and $0.34 \mathrm{ppm}$ and the activity ratio of ${ }^{234} \mathrm{U} /{ }^{238} \mathrm{U}$ ranging between 1.01 and 1.07 . Detrital contamination of $\mathrm{Th}$ is generally low, as indicated by high ratios of ${ }^{230} \mathrm{Th} /$ ${ }^{232} \mathrm{Th}$ (thorium ratio). Thorium ratios of less than about 15 are usually indicative of sufficient contamination to render the ages uncertain (Bischoff and Fitzpatrick, 1991). Of the 22 samples analyzed, only 6 have thorium ratios less than 15 .

Nominal dates range from 38,000 to $185,000 \mathrm{yr}$ B.P. In general, the dates increase in stratigraphic order, a good indicator of reliability (Figs. 4a and 4b). TRB was cut along a rather steep slope at the back of the cave. Core $J$ was taken from the top of this slope (Fig. 4b) and represents the greatest thickness of flowstone section crossed by the trenches, over $18 \mathrm{~cm}$ in all. The date at the top of this core is $38,000 \pm 4000 \mathrm{yr}$ B.P. and is the youngest date for a sample in the present study. It seems to represent a singular lobe of flowstone which does not extend laterally to the floor of the cave. The thorium ratio of 5 (Table 1) indicates considerable detrital contamination and that true age of the top of this core, therefore, is likely somewhat younger. The other dates going down the core show no detrital contamination and are in excellent stratigraphic succession indicating high confidence in their reliability. There is still considerable flowstone beneath the lowermost sample " e"' (108,000 yr B.P.) taken at 13 to $14 \mathrm{~cm}$, so the age of the basal flowstone on bedrock must be somewhat older. Cores K 

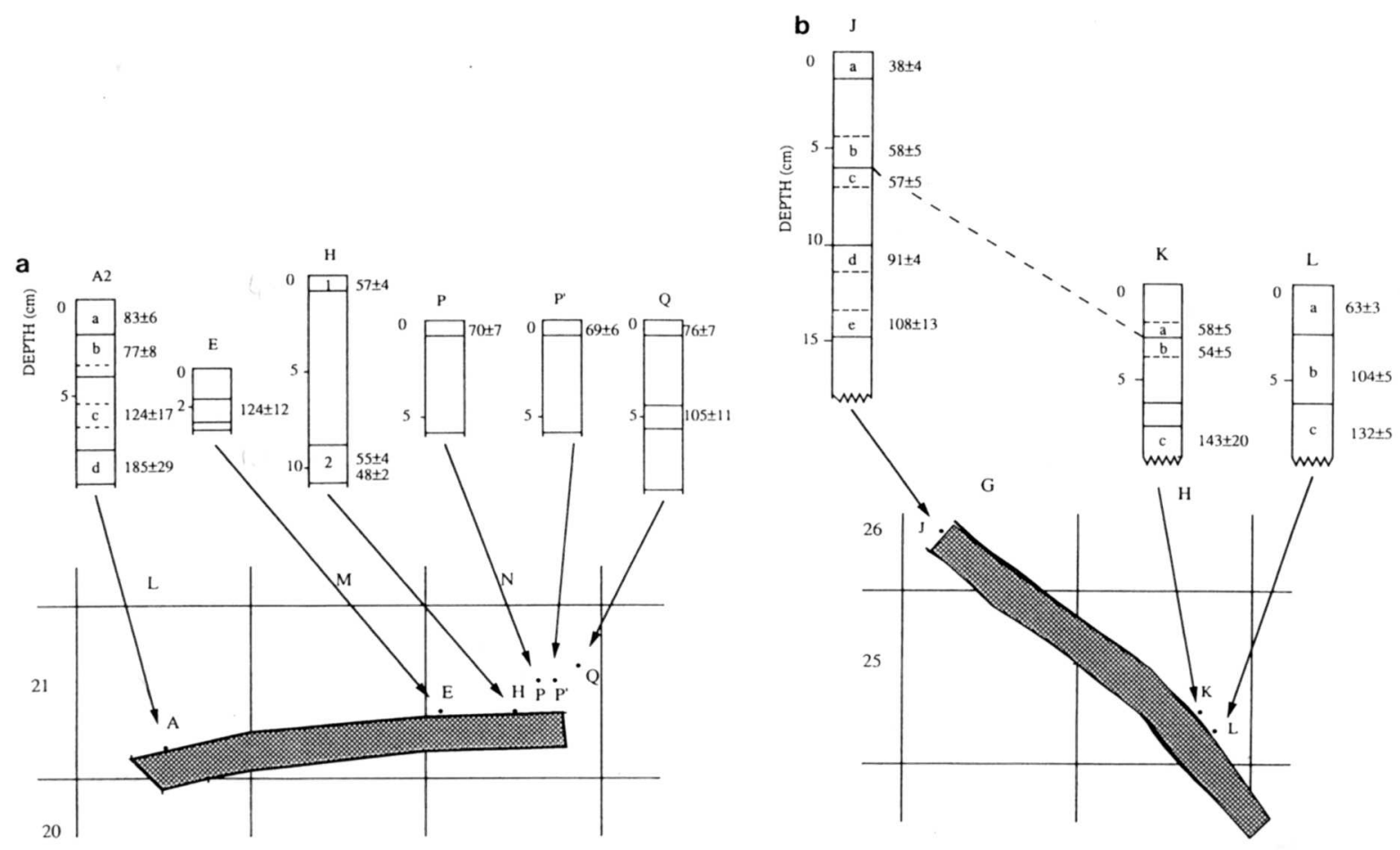

FIG. 4. (a) Stratigraphic relation between studied samples of TRA. Squares refer to Fig. 3 and are $1 \mathrm{~m}$ on each side. TRA cores (A2, E, H, P, $\left.\mathrm{P}^{\prime}, \mathrm{Q}\right)$ and TRB ones $(\mathrm{J}, \mathrm{K}, \mathrm{L})$ are shown in vertical section with arrows pointing to their map location. Dates $\left(10^{3} \mathrm{yr}\right)$ are shown at side of cores with $\pm 1 \sigma$ counting error. (b) Stratigraphic relation between studied samples of TRB. Squares refer to Fig. 3 and are 1 meter on each side. TRA cores (A2, E, H, $\left.\mathrm{P}, \mathrm{P}^{\prime}, \mathrm{Q}\right)$ and TRB cores $(\mathrm{J}, \mathrm{K}, \mathrm{L})$ are shown in vertical section with arrows pointing to their map location. Dates $\left(10^{3} \mathrm{yr}\right)$ are shown at side of cores with $\pm 1 \sigma$ counting error.

and $\mathrm{L}$ were taken adjacent to each other (Fig. 4b) and their dates are coherent with each other and with core J. The dates at the top of these cores are about $60,000 \mathrm{yr}$ B.P. and are believed to correlate with a level about $5 \mathrm{~cm}$ below the surface in core $J$. Dates for the bottom of these cores $(143,000$ and 132,000 yr B.P.) are probably somewhat too old because of detrital contamination.

TRA was cut in a flat portion of the floor of the cave, so all cores were taken from approximately the same elevation. However, the stratigraphy of the flowstone in this section is considerably more complicated than that seen in TRB. The flowstone is segmented and individual beds are discontinuous. Nevertheless, the pattern of dates is very similar to that seen for the cores from TRB, with the upper surface of the flowstone dating to about $60,000 \mathrm{yr}$ B.P. (cores H, P, $\mathrm{P}^{\prime}$, and Q, Fig. 4a). Sample 2d, the lowermost sample in core A and obtained immediately above the contact with the bedrock, yielded a date of $185,000 \mathrm{yr}$ B.P. The thorium ratio is 14 , indicating that detrital contamination is present; the date is deemed to be older than the age of the beginning of the formation of Ensemble $\mathrm{E}$. Sample 2 in core $\mathrm{E}$ is taken from the same horizon and yielded a date of $124,000 \mathrm{yr}$ B.P., but it has a thorium ratio of 6 . Sample 2 in core $\mathrm{H}$ is also adjacent to the bedrock but yielded an enigmatic date of $55,000 \mathrm{yr}$ B.P.; a replicate analysis yielded $48,000 \mathrm{yr}$ B.P. These dates are essentially the same as a $57,000 \mathrm{yr}$ date obtained at the surface of the same core; thus, the result is puzzling. There is no detectable ${ }^{232} \mathrm{Th}$ in either of these samples; thus, detrital contamination is insignificant. Core $\mathrm{H}$ was taken on an isolated outlier of the flowstone and the results suggest that the entire section represented by this core must have formed rather rapidly about $55,000 \mathrm{yr}$ B.P. on a fragment of discontinuously exposed bedrock. The top samples $\mathrm{P}, \mathrm{P}^{\prime}$, and $\mathrm{Q}$ yield similar ages of 70,000, 69,000, and 76,000 yr 
Table 1. U-Series Radiometric Data and Derived Dates on Flowstone Samples Taken from Drill Core From Grotte du LAZARET

\begin{tabular}{|c|c|c|c|c|c|c|}
\hline Sample & Lab. No. & $\begin{array}{c}\mathrm{U} \\
(\mathrm{ppm})\end{array}$ & ${ }^{234} \mathrm{U} /{ }^{238} \mathrm{U}$ & ${ }^{230} \mathrm{Th} /{ }^{232} \mathrm{Th}$ & $\begin{array}{c}\text { Date } \\
\left(10^{3} \text { yr B.P. }\right)\end{array}$ & Comment \\
\hline \multicolumn{7}{|c|}{ Samples taken from along trench TRA } \\
\hline $\mathrm{A} 2 \mathrm{a}$ & $87-107$ & 0.25 & 1.07 & 35 & $83 \begin{array}{l}+7 \\
-6\end{array}$ & \\
\hline $\mathrm{A} 2 \mathrm{~b}$ & $87-151$ & 0.29 & 1.03 & $>100$ & $77 \begin{array}{l}+8 \\
-7\end{array}$ & \\
\hline $\mathrm{A} 2 \mathrm{c}$ & $87-152$ & 0.17 & 1.06 & $>100$ & 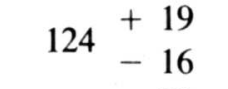 & \\
\hline $\mathrm{A} 2 \mathrm{~d}$ & $87-108$ & 0.34 & 1.05 & 14 & $\begin{array}{r}+29 \\
-23\end{array}$ & Slight contamination \\
\hline $\mathrm{E}$ & $87-110$ & 0.29 & 1.02 & 6 & $124 \begin{array}{r}+12 \\
-10\end{array}$ & Contamination \\
\hline H1 & $87-146$ & 0.22 & 1.06 & $>100$ & $57 \pm 4$ & \\
\hline $\mathrm{H} 2$ & $87-147$ & 0.21 & 1.06 & $>100$ & $55 \pm 4$ & \\
\hline $\mathrm{H} 2$ & $87-181$ & 0.23 & 1.02 & $>100$ & $48 \pm 2$ & \\
\hline $\mathrm{P}$ & $87-113$ & 0.22 & 1.01 & 28 & $70 \begin{array}{l}+7 \\
-6\end{array}$ & \\
\hline $\mathrm{P}^{\prime}$ & $87-116$ & 0.20 & 1.06 & 60 & $69 \pm 6$ & \\
\hline Q1 & $87-111$ & 0.21 & 1.03 & 16 & $76 \pm 7$ & \\
\hline Q2 & $87-112$ & 0.17 & 1.06 & 17 & $105 \begin{array}{r}+12 \\
-10\end{array}$ & \\
\hline \multicolumn{7}{|c|}{ Samples taken from cores along trench TRB } \\
\hline $\mathrm{Ja}$ & $87-114$ & 0.18 & 1.05 & 5 & $38 \pm 4$ & Contamination \\
\hline $\mathrm{Jb}$ & $87-148$ & 0.20 & 1.03 & $>100$ & $58 \pm 5$ & \\
\hline Jc & $87-157$ & 0.26 & 1.04 & $>100$ & $57 \pm 5$ & \\
\hline Jd & $87-180$ & 0.21 & 1.02 & $>100$ & $91 \pm 4$ & \\
\hline $\mathrm{Je}$ & $87-115$ & 0.15 & 1.03 & 130 & $108 \begin{array}{l}+14 \\
-12\end{array}$ & \\
\hline $\mathrm{Ka}$ & $87-117$ & 0.19 & 1.00 & 9 & $58 \pm 5$ & Contamination \\
\hline $\mathrm{Kb}$ & $87-159$ & 0.23 & 1.01 & $>100$ & $54 \pm 5$ & \\
\hline $\mathrm{Kc}$ & $87-118$ & 0.19 & 1.07 & 5 & $143 \begin{array}{l}+20 \\
-17\end{array}$ & Contamination \\
\hline $\mathrm{La}$ & $87-164$ & 0.19 & 1.06 & 21 & $63 \pm 3$ & \\
\hline $\mathrm{Lb}$ & $87-165$ & 0.15 & 1.05 & $>100$ & $104 \pm 5$ & \\
\hline $\mathrm{Lc}$ & $87-170$ & 0.24 & 1.02 & 8 & $132 \pm 5$ & Contamination \\
\hline
\end{tabular}

B.P.; a sample of intermediate depth in core $\mathrm{Q}$ gave a date of $105,000 \mathrm{yr}$ B.P.

These dates for the upper parts of the flowstone are all rather coherent, and taken together with Shen's (1985) results on the same flowstone in the central part of the cave point to a conclusion that Ensemble E ceased active formation about $70,000 \mathrm{yr}$ B.P., but that isolated parts next to the rear wall of the cave continued to form until about 35,000 yr B.P. The time when flowstone formation began is less clear because all the basal samples displayed rather low thorium ratios and hence detrital contamination. The oldest of the "clean" dates, from an intermediate depth in core A (sample $2 \mathrm{c}$ ), is $124,000 \pm 17,000$ yr B.P. We conclude that the $185,000 \mathrm{yr}$ B.P. date for the basal sample of this same core is too old and that the likely age is closer to 130,000 or $140,000 \mathrm{yr}$ B.P. as indicated by basal dates from cores K and L. Such a scenario would reasonably place the entire period of formation of Ensemble $E$ within stage 5 of the marine oxygen isotope chronology (Fig. 5) and would support the hypothesis that Ensemble $\mathrm{E}$ formed as a consequence of the humid conditions which locally prevailed during the last interglaciation.

Lazaret cave is an important middle 


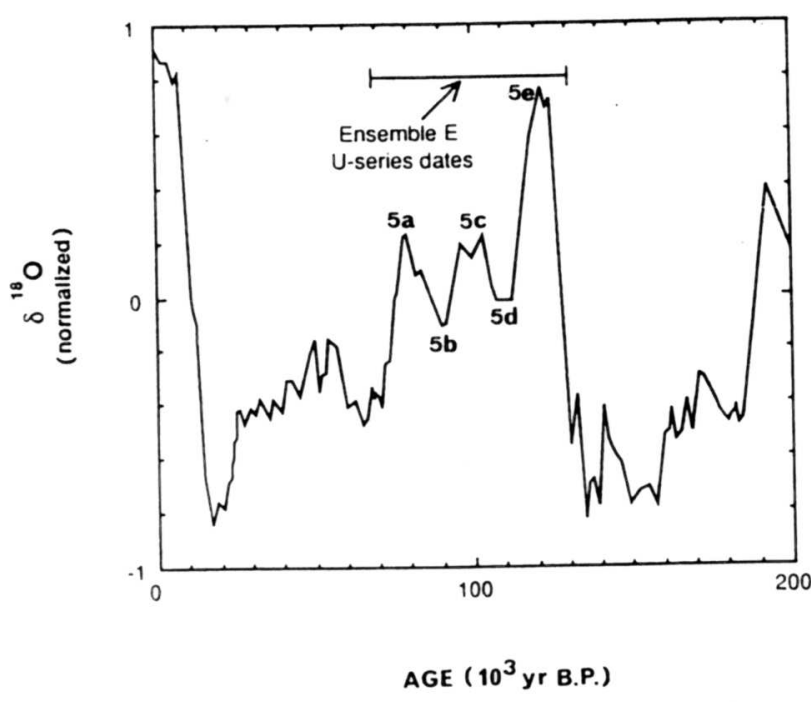

FIG. 5. Range of U-series dates obtained on Ensemble $\mathrm{E}$ shown on marine isotope stage diagram as plotted from data in Martinson et al. (1987). Isotopes stages $5 \mathrm{a}, 5 \mathrm{c}$, and $5 \mathrm{e}$ are shown for reference. U-series dates show that Ensemble E formed throughout isotope stage 5 .

Pleistocene site. Here, for the first time, the association of Pliomys lenki (Chaline, 1969) with a human Acheulian industry is observed. The ages obtained by U-Th methods of the flowstones of Ensemble $E$ fall between 130,000 and 70,000 yr B.P. Observations made in the central part of the cave, near the east wall, show that Ensemble E rests upon layers of Riss III age. The industry found in these layers is defined as "preMousterian" and rich in scrapers, with non-Levallois flaking. This industry dates to the beginning of the transition from Acheulian to Mousterian, a gradual evolution from handaxes to tools made on flakes. The radiometric results obtained on calcite of Ensemble E seem to suggest that this transition occurred sometime after the beginning of isotope stage $5 \mathrm{e}$ (after $120,000 \mathrm{yr}$ B.P.). These results are consistent with relations at El Castillo cave in Spain where the Acheulian appears to extend to about $89,000 \mathrm{yr}$ B.P. (Bischoff $e t$ al., in press).

\section{REFERENCES}

Bischoff, J. L., and Fitzpatrick, J. (1991). U-series dating of impure carbonates: An isochron technique using total-sample dissolution. Geochimica et Cosmochimica Acta 55,

Bischoff, J. L., Garcia, J. F., and Straus, L. G. (In press). Uranium-Series Isochron Dating at El Castillo cave (Cantabria, Spain): The "Acheulian"/ "Mousterian"' question. Journal of Archaeological Science.

Bischoff, J. L., Rosenbauer, R. J., Tavoso, A., and de Lumley, H. (1988). A test of uranium-series dating of fossil tooth enamel: Results from Tournal cave, France. Applied Geochemistry, 3, 135-141.

Chaline, J. (1969). Les rongeurs découverts sur le sol de la cabane acheuléenne du Lazaret. Mémoire de la Société Préhistorique Française 7, 85-93.

de Lumley, H. (1969). Les méthodes de fouilles préhistoriques. Mémoire de la Société Préhistorique Française 7, 13-17.

de Lumley, H. (1969). Le Paléolithique inférieur et moyen du midi méditerranéen dans son cadre géologique. Ve supplément à Gallia Préhistoire 1,

de Lumley, H., de Lumley, M. A., Miskovsky, J. C., and Renault-Miskovsky, J. (1976). La grotte du Lazaret. "Livret-Guide B1 de l'UISPP: Sites paléolithiques de la région de Nice et grottes de Grimaldi, IX Congress,'” pp. 53-74.

de Lumley, H., and Tavoso, A. (1969). La stratigraphie des couches suprérieures de la grotte du Lazaret. Mémoire de la Société Préhistorique Française 7, 17-24.

de Lumley, M. A. (1973). Anténéandertaliens et Néandertaliens du Bassin Méditerranéen Occidental. Etudes Quaternaires Memoir 2.

de Lumley, M. A., and Piveteau, J. (1969). Les restes humains de la grotte du Lazaret (Nice, Alpes Maritimes). Mémoire de la Société Préhistorique Française 7, 223-232.

Martinson, G., Pisias, N., Hays, J., Imbrie, J., Moore, T., Jr., and Shackleton, N. (1987). Age dating and the orbital theory of the ice ages: Development of a high-resolution 0 to 300,000 year chronostratigraphy. Quaternary Research 27, 1-29.

Octobon, F. C. E. (1965). Grotte du Lazaret, (A-M). Huitième étude sur les fouilles exécutées dans le Locus VIII de cette grotte (ancienne grotte Lympia) et sur la géologie quaternaire locale. Bulletin $\mathrm{du} M \mathrm{Mu}^{-}$ sée d'Anthropologie Préhistorique de Monaco 12, 23-101.

Shen, G. (1985). "Datation des planchers stalagmitiques de sites acheuléens en Europe par les méthodes des déséquilibres des familles de l'uranium et contribution méthodologique. Unpublished Thèse de doctorat d'Etat, Université P. et M. Curie, Paris VI.

Stearns, C. E., and Thurber, D. L. (1965). Th230U234 dates of late Pleistocene marine fossils from the Mediterranean and Moroccan littorals. Quaternaria 7, 29-42. 